\title{
Reduced nitrate concentrations in shallow ground water under a non-fertilised grass buffer strip
}

\author{
Christy L. van Beek • Marius Heinen • \\ Olga A. Clevering
}

Received: 26 June 2006 / Accepted: 20 February 2007 / Published online: 6 April 2007

(C) Springer Science+Business Media B.V. 2007

\begin{abstract}
In this paper the suitability of a buffer strip to reduce nitrate concentrations in the upper groundwater was tested for a sandy arable soil in The Netherlands during two consecutive leaching seasons. The bufferstrip was a $3.5 \mathrm{~m}$ wide unfertilised grass strip adjacent to a ditch on an arable field. In total 24 groundwater wells were installed in 4 transects perpendicular to the ditch to determine $\mathrm{Cl}, \mathrm{NO}_{3}$ and $\delta^{15} \mathrm{~N}$ concentrations. Piezometers were installed to assess the groundwater flow, which was in the direction of the ditch with small downward leakage across a peat layer at about $3 \mathrm{~m}$ depth. Nitrogen was dominantly present as nitrate $\left(\mathrm{NO}_{3}\right)$. The $\mathrm{NO}_{3}-\mathrm{N}$ concentrations under the bufferstrip were significantly lower than under the adjacent arable field. The lower concentrations were due to dilution, uptake by grass and denitrification. Nitrate was actively removed in the bufferstrip, since the $\mathrm{Cl} / \mathrm{NO}_{3}$ ratios were higher in the bufferstrip than in the remainder of the field. Furthermore, $\delta^{15} \mathrm{~N}$ data
\end{abstract}

C. L. van Beek $(\varangle) \cdot$ M. Heinen

Alterra, Wageningen University and Research Centre, P.O. Box 47, Wageningen 6700 AA, The

Netherlands

e-mail: christy.vanbeek@wur.nl

O. A. Clevering

Applied Plant Research (PPO-AGV), Wageningen University and Research Centre, P.O. Box 430, 8200

AK Lelystad, The Netherlands indicated that denitrification occurred in the groundwater and increased with decreasing distance to the ditch. $\mathrm{NO}_{3}-\mathrm{N}$ loads to the ditch were estimated at $8.5 \mathrm{~kg} \mathrm{ha}^{-1} \mathrm{yr}^{-1}$, which is relatively low for this area. We can, however, not determine whether these relatively low $\mathrm{NO}_{3}-\mathrm{N}$ loads were causally related to the reduced $\mathrm{NO}_{3}-\mathrm{N}$ concentrations in the bufferstrip. Nevertheless, the results of the present study are promising and justify additional research on the efficiency of bufferstrips to reduce $\mathrm{NO}_{3}$ concentrations in shallow groundwater, and subsequently reduce $\mathrm{NO}_{3}$ loading of surface water, under Dutch conditions.

Keywords Nitrate $\cdot$ Bufferstrip $\cdot 15 \mathrm{~N}$.

Denitrification · Groundwater

\section{Introduction}

Nutrient loading, specifically nitrogen (N) and phosphorus $(\mathrm{P})$, of surface waters in the Netherlands generally exceed preliminary targets set by the EU (Framework Water Directive, Nitrate Directive). Since the end of the previous century $\mathrm{N}$ and $\mathrm{P}$ loads to surface water from point sources have decreased considerably (Oenema and Roest 1998) and currently the focus is on non-point sources (Hefting 2003). In the Netherlands, non-point sources of $\mathrm{N}$ and $\mathrm{P}$ originate mainly 
from agricultural inputs (Orleans et al. 1994; Oenema and Roest 1998; Hefting 2003). To reduce non-point loads of nutrients from agriculture, source oriented and effect oriented measures are taken. Source oriented measures are directed towards reducing nutrient surplus in soils, for example, reduced applications of fertiliser or growing catch crops. Effect oriented measures aim at removing $\mathrm{N}$ and $\mathrm{P}$ during their transport from soil leaching towards surface waters. Although source oriented measures are generally preferred above effect oriented measures, source oriented measures alone will not yield enough reduction to achieve preliminary targets set by the EU (Orleans et al. 1994) and therefore additional measures are required.

Additional measures like constructed and riparian wetlands, bio-screens and buffer strips have been used successfully in reducing or retaining contaminants from run-off water or shallow groundwater (Hefting 2003). Buffer strips are generally defined as permanent vegetated strips, having a width between one and $100 \mathrm{~m}$, along open water systems with a different management than the remainder of the field (Muscutt et al. 1993). They act as a biochemical and physical barrier between potential sources of contamination (the remainder of the field) and the adjacent open water system. In many (model) studies buffer strips were effective in reducing loads of $\mathrm{N}$ and $\mathrm{P}$ towards open water systems (e.g., PeterJohn and Correll 1984; Lowrance et al. 1984; Orleans et al. 1994; Vought et al. 1994; Kuusemets et al. 2001; Borin and Bigon 2002; Sabater et al. 2003), but exceptions were found that were attributed to specific hydrological conditions or, for $\mathrm{P}$, to the release of $\mathrm{P}$ due to reducing circumstances during wetting (LeedsHarrison et al. 1999; Komor and Magner 1996).

Dinnes et al. (2002) reported efficiencies of buffer strips in reducing $\mathrm{N}$ and $\mathrm{P}$ loads of surface water of $48 \%$ to almost $100 \%$. The efficiency was mainly related to the width of the buffer strip. Typically, these studies were conducted on sloping fields with shallow groundwater levels $(<3 \mathrm{~m})$ and/or with a shallow, nearly impermeable soil layer (e.g., Hefting and De Klein 1998; De Klein and Hefting 1998; Dhondt et al. 2002; Lowrance et al. 2000; Haycock and Burt 1993; Haycock and
Pinay 1993; Novak et al. 2002; Mengis et al. 1999). Such conditions (i.e. sloping fields and impermeable soil layers) are generally not present in flat delta areas, such as in The Netherlands. In the Netherlands agricultural fields can be typified as flat with shallow groundwater levels and high density of drainage systems (tile drains, ditches, canals). These conditions are likely to reduce the effectiveness of buffer strips in retaining leached $\mathrm{NO}_{3}^{-}$, because they allow by-passing of the buffer strip. Results achieved in international studies may therefore not be applicable to Dutch conditions.

Experimental research on the functionality of buffer strips is complex, because on-site nutrient loads are difficult to quantify and replicates are generally not at hand. In most studies on buffer strips a compromise between experimental requirements and practic constraints is found in measuring nutrient concentrations in groundwater in one or more transects perpendicular to the surface water (e.g., Hefting and De Klein 1998). Additionally, process understanding can be attained by e.g., determination of $\mathrm{Cl} / \mathrm{NO}_{3}$ ratios differences in natural abundance of ${ }^{15} \mathrm{~N}$ (denoted as $\delta^{15} \mathrm{~N}$ ) of $\mathrm{NO}_{3}-\mathrm{N}$ in groundwater. An increase in the $\mathrm{Cl} / \mathrm{NO}_{3}$ ratio indicates that nitrate removal processes occur, e.g., denitrification (Altman and Parizek 1995; Mengis et al. 1999). Crop uptake also results in increasing $\mathrm{Cl} / \mathrm{NO}_{3}$ ratios because relative $\mathrm{NO}_{3}$ uptake rates exceed $\mathrm{Cl}$ uptake rates (Marschner 2002). Dilution alone is eliminated as this would not result in a change in this ratio, except when the diluting water has a different $\mathrm{Cl} / \mathrm{NO}_{3}$ ratio itself. An increase in $\delta^{15} \mathrm{~N}$ towards open water systems and an increase with nitrate concentration are strong indications that nitrate is reduced by denitrification, since denitrifying micro-organisms preferentially assimilate the lighter isotope $\left({ }^{14} \mathrm{~N}\right)$ above the heavier isotope $\left({ }^{15} \mathrm{~N}\right)$ and the fractionation due to denitrification exceeds the fractionation due to root uptake and immobilisation (Mayer et al. 2002; Bedard-Haughn et al. 2003). Hence, by combining insights obtained from $\mathrm{Cl} / \mathrm{NO}_{3}$ ratios and $\delta^{15} \mathrm{~N}$ values of groundwater, process information about the dynamics of $\mathrm{NO}_{3}$ in the buffer strip and adjacent arable field can be obtained. 
The aim of this study was to study the dynamics of $\mathrm{NO}_{3}$ in groundwater between a fertilised, arable soil and an adjacent permanently vegetated (grass) buffer strip for a non-drained, flat, sandy soil in order to examine the effectiveness of a buffer strip in reducing $\mathrm{N}$ loads to surface water in The Netherlands. Since measuring actual loads of nutrients towards open water systems is complicated, we followed the approach commonly used, namely measuring nitrate concentrations in shallow groundwater (Dhondt et al. 2002; Altman and Parizek 1995; Lowrance et al. 2000; Sabater et al. 2003; Borin and Bigon 2002; Haycock and Burt 1993; Haycock and Pinay 1993; Kuusemets et al. 2001; Novak et al. 2002; Mengis et al. 1999). We also considered changes in $\mathrm{Cl} / \mathrm{NO}_{3}$ ratios and in $\delta^{15} \mathrm{~N}$ in groundwater as indicators for nitrate removal.

\section{Materials and methods}

\section{Location}

Measurements were carried out on research farm 'Vredepeel' in the south-east of the Netherlands $\left(51^{\circ} 32^{\prime \prime} \mathrm{N}, 5^{\circ} 52^{\prime \prime} \mathrm{E}\right.$, altitude $27 \mathrm{~m}$ a.s.l.). The experimental field was $69 \mathrm{~m}$ wide and $200 \mathrm{~m}$ long with ditches at both short ends. Along the ditch at the south side, with discharge from about $100 \mathrm{~m}$ field length, a non-fertilised grass buffer strip (BS) was established in 1999. The BS mainly consisted of red fescue, which was cut annually coinciding with a removal of $55 \mathrm{~kg} \mathrm{~N} \mathrm{ha}^{-1} \mathrm{yr}^{-1}$ (Van Beek et al. 2005). The soil was a sandy gley podzol according to FAO classification and main characteristics of the soil are listed in Table 1. At a depth of 2.75 to $3.25 \mathrm{~m}$ a peat layer was present with a rather high resistance to flow that may act as a physical barrier for water movement and nutrient transport (De Vos et al. 2002). The arable field adjacent to the BS is referred to as AF.

The soil surface was nearly flat: the field margin along the ditch was about $30 \mathrm{~cm}$ lower than the middle of the field (average slope $0.3 \%$ ). The waterlevel in the ditch fluctuated from zero (no water in the ditch) to $40 \mathrm{~cm}$, the latter corresponding to about $85 \mathrm{~cm}$ below soil surface
Table 1 Soil characteristics at experimental farm 'Vredepeel' (Boesten and Van der Pas 2000)

\begin{tabular}{|c|c|c|c|}
\hline \multirow[t]{2}{*}{ Property } & \multicolumn{3}{|l|}{ Soil layer } \\
\hline & $0-25 \mathrm{~cm}$ & $50-100 \mathrm{~cm}$ & $100-200 \mathrm{~cm}$ \\
\hline $\mathrm{pH}-\mathrm{KCl}$ & 5.3 & 4.7 & 4.6 \\
\hline $\begin{array}{l}\text { Organic } \\
\text { matter }(\%)\end{array}$ & $4.9(0.0)$ & & \\
\hline $\begin{array}{l}\text { Organic } \\
\quad \text { carbon }(\%)\end{array}$ & $2.29(0.03)$ & $0.11(0.02)$ & $0.12(0.06)$ \\
\hline $\mathrm{CaCO}_{3}$ & 0.1 & & \\
\hline $\begin{array}{l}\text { Clay }(0-2 \mu \mathrm{m} \\
\text { in } \%)\end{array}$ & 3 & 2 & 3 \\
\hline $\begin{array}{l}\text { Silt }(2-50 \mu \mathrm{m} \\
\quad \text { in } \%)\end{array}$ & 6 & 2 & 9 \\
\hline $\begin{array}{l}\text { Sand }(50-2000 \mu \mathrm{m} \\
\text { in } \%)\end{array}$ & 91 & 96 & 88 \\
\hline
\end{tabular}

Numbers between parentheses indicate standard deviations $(n=3)$

(-ss). Typically, during summer the groundwater table was between 200 and $250 \mathrm{~cm}$-ss and during winter between 75 and $125 \mathrm{~cm}$-ss.

Measurements were carried out during two consecutive leaching seasons (2003-2004 and 2004-2005), where a leaching season is defined as the period during which precipitation exceeds evapotranspiration. In the Netherlands, the leaching season typically runs from October till April next year. Measurements in the AF were paused during the growing season to allow agricultural activities, while in the BS measurements were continued until the ground water level dropped below the wells.

Rain, reference evapotranspiration and sampling frequency

Sampling of the upper groundwater was aimed at every $30 \mathrm{~mm}$ of effective rainfall, i.e. rainfall minus reference evapotranspiration. Rainfall was measured on-site and daily rainfall amounts were recorded. Compared to rainfall, evapotranspiration is more constant over larger areas. We used the averaged measured reference evapotranspiration data from three nearby (within $35 \mathrm{~km}$ ) Royal Dutch Meteorological Institute weather stations (http://www.knmi.nl), namely, Arcen (5130 N, $6^{\circ} 12 \mathrm{E}, 19 \mathrm{~m}$ a.s.l.), Volkel $\left(51^{\circ} 39 \mathrm{~N}, 5^{\circ} 42 \mathrm{E}\right.$, $20 \mathrm{~m}$ a.s.l.) and Eindhoven (51 $27 \mathrm{~N}, 5^{\circ} 25 \mathrm{E}$, $20 \mathrm{~m}$ a.s.l.). Reference evapotranspiration data 
(for $10 \mathrm{~cm}$ height grass) are computed from the incoming short-wave radiation and daily average temperature (used to compute the slope of the vapour pressure curve at this temperature) according to Makkink (1957; see also De Bruin 1987). The Makkink method is derived from the Penman (1948) and Priestley-Taylor (1972) method. However, since evapotranspiration during the leaching season is very small and the data were not on-line available, effectively the times of sampling were based on measured rainfall only and results were recalculated to effective rainfall afterwards. This sampling procedure resulted in 11 sampling events in 2003-2004 and 10 sampling events in 2004-2005.

\section{Experimental design}

Groundwater samples were taken in four transects (A to D) perpendicular to the ditch. Each of the four transects consisted of six sampling wells at $0.5,3,4,9,40$ and $100 \mathrm{~m}$ from the ditch. The $210 \mathrm{~cm}$ long wells were fully perforated and had an inner diameter of $32 \mathrm{~mm}$. The transects were situated $10 \mathrm{~m}$ apart. For the determination of $\delta^{15} \mathrm{~N}$ multi-port wells were installed that allowed for sampling at distinct depths at $30-50 \mathrm{~cm} \mathrm{-ss,}$
50-80 cm -ss, $80-110 \mathrm{~cm}$-ss and $110-140 \mathrm{~cm}$-ss (Fig. 1).

Four automatic groundwater table wells were installed: two in the middle of the BS and two in the middle of the AF. Twelve piezometers were installed in two transects near the sampling wells at $210 \mathrm{~cm}$-ss. In the second season additional piezometers (18) were installed at the same sites just above the peat layer $(275 \mathrm{~cm}-\mathrm{ss}, 12)$, in the ditch (2) and at $450 \mathrm{~cm}$-ss (4) (Fig. 1). Differences in groundwater levels from the middle of the field towards the ditch and gradients in total heads were used to determine dominant flow paths of water. The gradient in total heads between the shallow and deep piezometers were used to determine vertical water movements across the peat layer.

Chemical analyses

Before sampling the wells were pumped empty and allowed to settle again. Water samples were filtered over $0.45 \mu \mathrm{m}$ filters, stored at maximum $4^{\circ} \mathrm{C}$ and analysed within a few days. Each water sample was analysed for $\mathrm{NO}_{3}-\mathrm{N}, \mathrm{NH}_{4}-\mathrm{N}, \mathrm{N}_{\text {ts }}$ (total soluble $\mathrm{N}$ ), $\mathrm{P}_{\mathrm{t}}, \mathrm{PO}_{4}-\mathrm{P}$ and $\mathrm{Cl}$. The sum of $\mathrm{NO}_{3}-\mathrm{N}$ and $\mathrm{NH}_{4}-\mathrm{N}$ forms the mineral part of $\mathrm{N}$,
Fig. 1 Field design and experimental set-up (not on scale, distances in $\mathrm{m}$ ). Legends shown in italic were added to the field in 2004

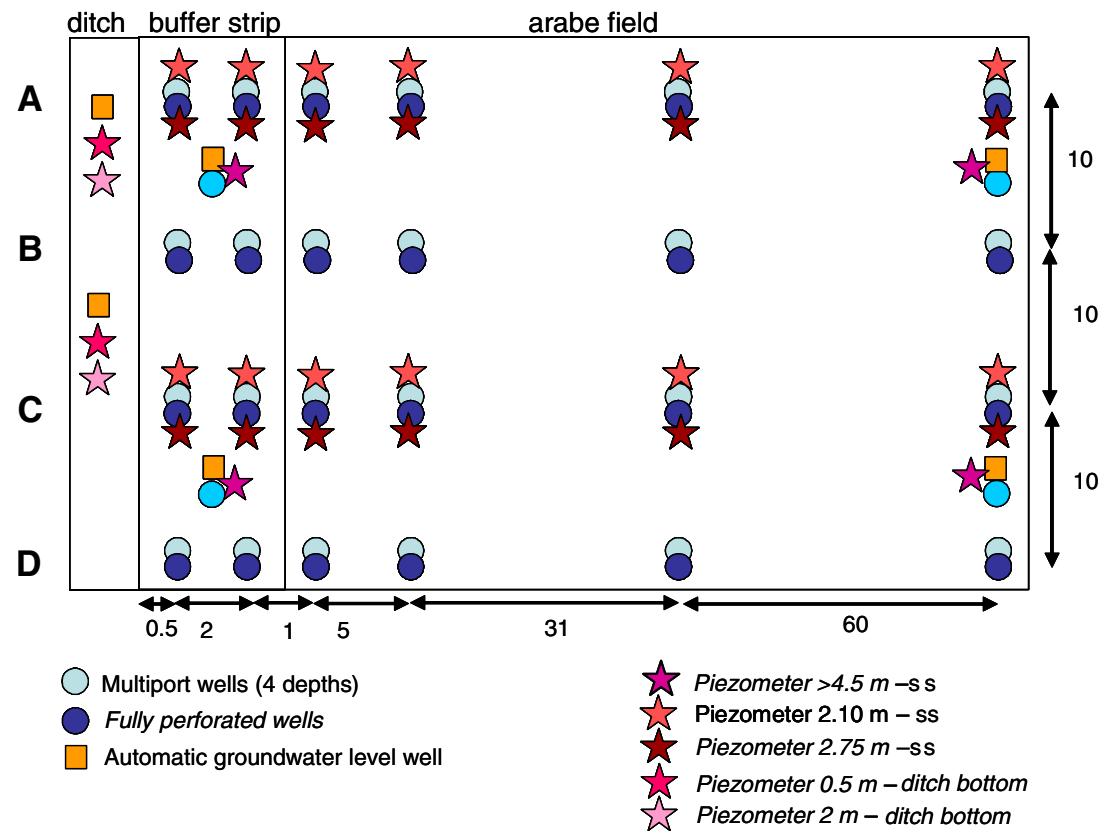


and the difference between $\mathrm{N}_{\text {ts }}$ and the mineral part is dissolved organic $\mathrm{N}(\mathrm{DON})$.

The natural abundance of ${ }^{15} \mathrm{~N}$ in the mineral fraction of dissolved $\mathrm{N}$ was determined by microdiffusion (Stark and Hart 1996) as modified by Van Groenigen et al. (2005). Total $\mathrm{N}$ and $\delta^{15} \mathrm{~N}$ of the samples were measured at UC Davis Stable Isotope Facility using a continuous flow isotope ratio mass spectrometer (CF-IRMS, Europa Scientific, Crewe, UK), interfaced with a $\mathrm{CN}$ sample converter. The $\delta^{15} \mathrm{~N}$ values were corrected for residual tracer using blancs and are expressed relative to atmospheric $\mathrm{N}_{2}(\%)$.

\section{Statistics}

Significant differences in $\mathrm{NO}_{3}$ concentrations and $\mathrm{Cl} / \mathrm{NO}_{3}$ ratios under the $\mathrm{BS}$ and $\mathrm{AF}$ were tested by analysis of variance (using Genstat 7, 2003) for two situations with factor distance to the ditch $(0.5,3,4,9,40,100 \mathrm{~m})$ or location (BS, AF). The sampling times were used as a stratum in the analysis.

Linear trends in seasonal-averaged $\mathrm{NO}_{3}-\mathrm{N}$ concentrations towards the ditch were tested by a piece-wise linear model (using Genstat 7, 2003), defined by

$C_{i}=b_{0}+b_{1} x_{i}+b_{2}\left\{\left(x_{i}-x_{\text {buffer }}\right) i_{\text {field }}\right\}+\varepsilon_{i}$

where $C$ is the seasonal-averaged $\mathrm{NO}_{3}-\mathrm{N}$ concentration at location $i\left(\mathrm{mg} \mathrm{N}^{-1}\right), x$ is the distance to the ditch $(\mathrm{m}), x_{\text {buffer }}$ is the interface between BS and AF ( $\left.x_{\text {buffer }}=3.5 \mathrm{~m}\right), i_{\text {field }}$ is an indicator that determines if the location is in the $\mathrm{BS}\left(i_{\text {field }}=0\right)$ or in the $\mathrm{AF}\left(i_{\text {field }}=1\right), b_{0}, b_{1}$ and $b_{2}$ are regression coefficients (with units $\mathrm{mg} \mathrm{N}^{-1}$, $\mathrm{mg} \mathrm{N}^{-1} \mathrm{~m}^{-1}$, and $\mathrm{mg} \mathrm{N}^{-1} \mathrm{~m}^{-1}$, respectively), and $\varepsilon$ is the residual $\left(\mathrm{mg} \mathrm{N}^{-1}\right)$. The seasonal averages were taken for each sampling well separately, resulting in 24 values $i$ per season. It was assumed that the residuals are (spatially) independent and normally distributed with variance $\sigma^{2}$. The weights for the weighted least square optimisation were proportional to the inverse of the variances $\sigma_{i}^{2}$ belonging to the season averages, according to $w_{i}=\frac{n\left(\sigma_{i}^{2}\right)^{-1}}{\sum_{i=1}^{n}\left(\sigma_{i}^{2}\right)^{-1}}$

The variance $\sigma_{i}^{2}$ was estimated from the variance of the average concentration divided by the number of observations. Note that the sum of all weights equals the number of locations, i.e. $n=24$.

Discharge and $\mathrm{NO}_{3}$ load to ditch water

Due to fluctuating groundwater levels and downwards groundwater recharge, $\mathrm{NO}_{3}$ load towards the ditch could not be estimated as the product of effective rainfall times concentration of $\mathrm{NO}_{3}-\mathrm{N}$ under the BS. Therefore, we used the classical drainage theory of Hooghoudt (as given by Van der Ploeg et al. 1999) to estimate the water discharge to the ditch, in formula given as:

$Q=\frac{8 K D m_{o}+4 K m_{0}^{2}}{L^{2}}$

where $Q$ is the water discharge $\left(\mathrm{m} \mathrm{d}^{-1}\right), K$ is the hydraulic conductivity at saturation for horizontal water movement $\left(\mathrm{m} \mathrm{d}^{-1}\right), D$ is the thickness of the soil layer below the water level in the ditch $(\mathrm{m}), L$ is the distance between two ditches $(\mathrm{m})$, and $m_{0}$ is the difference between water table height at $L / 2$ and the water level in the ditch (m). Discharge was calculated for the upper $2.75 \mathrm{~m}$ and $D$ was estimated at $1.4 \mathrm{~m}$ (Fig. 2). With $D$ being much smaller than $L(L=200 \mathrm{~m})$, the physical thickness $D$ could be used instead of an effective thickness. The difference between water table heights, $m_{0}$, was measured at 6 hours interval. We used averaged daily values to compute daily values for $Q$. We used vertical $K$ values of $1.5 \mathrm{~m} \mathrm{~d}^{-1}$ according to De Vos et al. (2002) for the upper $35-70 \mathrm{~cm}$. Generally, the horizontal $K$ is larger (anisotropy) and De Vries (1974) compiled measured vertical and horizontal $K$ values for sandy soils in the south-eastern part of the Netherlands and found that the horizontal $K$ is 2 times the value of the vertical $K$. Therefore, we will use $K=3 \mathrm{~m} \mathrm{~d}^{-1}$ in Eq. (3). 


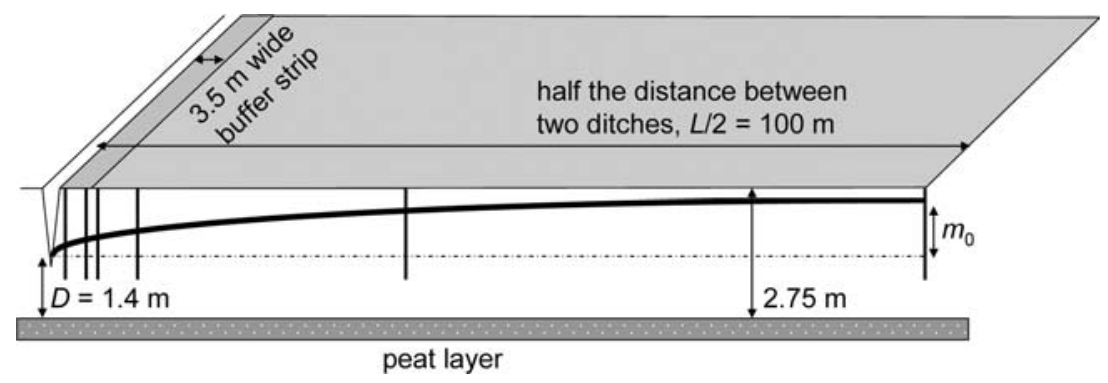

Fig. 2 Schematic representation of the hydrological system showing the dimensions. The figure is at scale, except that the vertical dimensions have been stretched by a

The $\mathrm{NO}_{3}-\mathrm{N}$ load towards the ditch was computed as follows:

$Q_{\mathrm{NO}_{3}-\mathrm{N}}=Q C_{0.5} 10$

where $Q_{\mathrm{NO}^{3}}-\mathrm{N}$ is the $\mathrm{NO}_{3}-\mathrm{N}$ load towards the ditch $\left(\mathrm{kg} \mathrm{N} \mathrm{ha}^{-1}\right), Q$ is the water discharge as computed from Eq. (3) $\left(\mathrm{m} \mathrm{d}^{-1}\right), C$ is the $\mathrm{NO}_{3}-\mathrm{N}$ concentration measured in the sampling well located $0.5 \mathrm{~m}$ from the ditch $\left(\mathrm{mg} \mathrm{N}^{-1}\right)$, and the factor 10 is a units conversion factor $\left(1000 \mathrm{l} \mathrm{m}^{-3}\right.$ times $0.01 \mathrm{~kg} \mathrm{ha}^{-1}$ per $\mathrm{mg} \mathrm{m}^{-2}$ ).

For each leaching season the groundwater levels were automatically recorded 4 times a day, from which the daily average was computed and used to obtain $m_{0}$. Concentrations $C_{0.5}$ for each day were obtained through linear interpolation from the measured data.

\section{Results}

\section{Hydrology}

The total rainfall during the two leaching seasons (1st October-1st April) was $400 \mathrm{~mm}$ and $370 \mathrm{~mm}$, respectively, while the effective rainfall was $290 \mathrm{~mm}$ and $260 \mathrm{~mm}$, respectively. During the first season the groundwater level rose from below the ditch floor in September 2003 up to about $40 \mathrm{~cm}$-ss in February 2004, and gradually decreased afterwards. During the second season groundwater levels were deeper than in the first season. Groundwater levels in the middle of the field were higher than in the BS. Together with clear head gradients towards the ditch (Fig. 3) factor 5. The six vertical lines indicate the positions of the sampling wells, and the curved line represents the position of the groundwater table

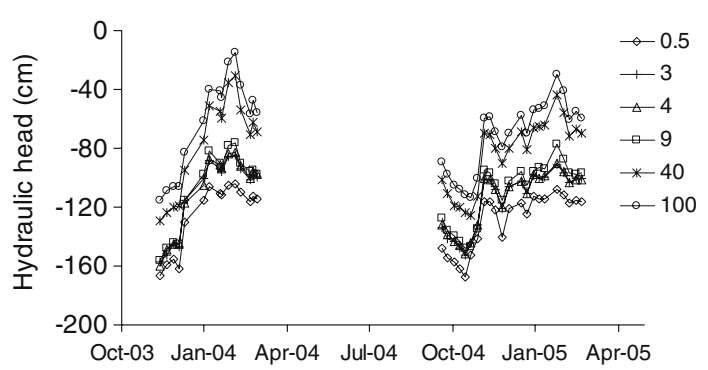

Fig. 3 Hydraulic heads (average of two transects) during the two leaching seasons. Different symbols refer to different distances to ditch $(\mathrm{m})$

this indicates that the dominant flow of groundwater was towards to the ditch. The piezometer readings in the two transects indicated that sometimes flow was also directed parallel to the ditch. Piezometers located at $210 \mathrm{~cm}$-ss always showed higher heads than the piezometers located at $450 \mathrm{~cm}$-ss, and indicated that there was downward water potential of about $0.134 \mathrm{~m} \mathrm{~m}^{-1}$.

\section{Solutes}

Concentrations of $\mathrm{P}\left(\mathrm{P}_{\mathrm{t}}\right.$ and $\left.\mathrm{PO}_{4}-\mathrm{P}\right)$ were mostly below the detection limit of $0.06 \mathrm{mg} \mathrm{l}^{-1}$ and $0.055 \mathrm{mg} \mathrm{l}^{-1}$, respectively, and were therefore left out for further analysis.

On average $86 \%$ of $\mathrm{N}_{\mathrm{ts}}$ was mineral N. In $91 \%$ of the cases $\mathrm{NO}_{3}-\mathrm{N}$ concentrations exceeded $\mathrm{NH}_{4}-\mathrm{N}$ concentrations, with $\mathrm{NH}_{4}-\mathrm{N}$ below the detection limit $\left(<0.14 \mathrm{mg} \mathrm{N}^{-1}\right)$ in $78 \%$ of the cases. The $\mathrm{NO}_{3}$ target level of $50 \mathrm{mg} \mathrm{l}^{-1}(11.3 \mathrm{mg}$ $\mathrm{N}^{-1}$ ) of the EU Nitrate Directive was exceeded frequently, especially in the second season and in 

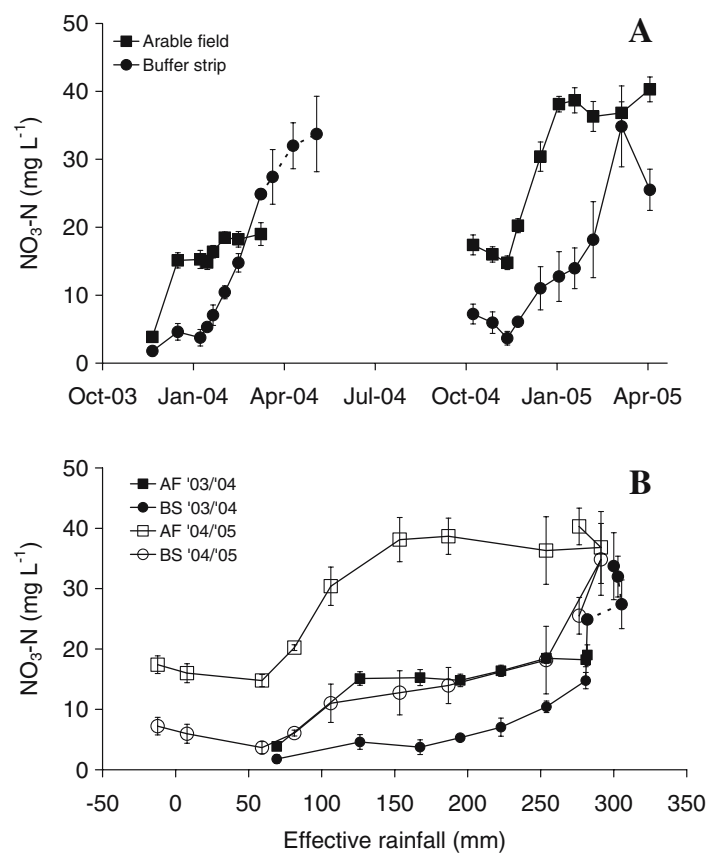

Fig. 4 Average $\mathrm{NO}_{3}-\mathrm{N}$ concentrations in the $\mathrm{BS}$ and $\mathrm{AF}$ for the two leaching seasons as function of time (a) and as function of effective rainfall (b). Error bars show standard errors ( $n=2$ for $\mathrm{BS}$ and $n=4$ for $\mathrm{AF}$ ). In the growing season analytical equipment was removed from the arable field to allow for agricultural practices

early spring of the first season (Fig. 4). Figure 4 shows the development of the average concentration of $\mathrm{NO}_{3}-\mathrm{N}$ in the $\mathrm{BS}$ and in the $\mathrm{AF}$ with time and with the cumulative effective rainfall. Initially, $\mathrm{NO}_{3}-\mathrm{N}$ concentrations in the $\mathrm{BS}$ were considerably below the $\mathrm{NO}_{3}-\mathrm{N}$ concentrations in the AF. However, during the first leaching season
$\mathrm{NO}_{3}-\mathrm{N}$ concentrations in the $\mathrm{BS}$ increased and in March 2004 (at $280 \mathrm{~mm}$ effective rainfall) exceeded the $\mathrm{NO}_{3}-\mathrm{N}$ concentrations in the AF. In the second leaching season the $\mathrm{NO}_{3}-\mathrm{N}$ concentrations in the $\mathrm{BS}$ were always below the $\mathrm{NO}_{3}-\mathrm{N}$ concentrations in the AF. Only in March 2005 (300 $\mathrm{mm}$ effective rainfall) there was little difference in $\mathrm{NO}_{3}-\mathrm{N}$ concentrations. Also in the second season the concentrations increased in time and with effective rainfall.

The analysis of variance (Table 2) showed that in both leaching seasons $\mathrm{NO}_{3}-\mathrm{N}$ concentrations and $\mathrm{Cl} / \mathrm{NO}_{3}-\mathrm{N}$ ratios under the $\mathrm{BS}$ were significantly lower than in the AF. At $3 \mathrm{~m}$ (BS) however sometimes no significant difference with AF was found. The linear trend analysis according to Eq. (2) showed good correspondence with seasonal-averaged $\mathrm{NO}_{3}-\mathrm{N}$ concentrations (Fig. 5; Table 3 ) and adjusted $R^{2}$ was about $80 \%$ for the first leaching season and about $88 \%$ for the second leaching season. The linear trend analysis showed distinct decreasing concentrations in the $\mathrm{BS}$ in the direction of the ditch. This gradient was stronger in the second season than in the first season. Outside the BS the concentrations tend to decrease with increasing distance from the ditch.

\section{$\mathrm{Cl} / \mathrm{NO}_{3}$ ratios and ${ }^{15} \mathrm{~N}$}

In both leaching seasons $\mathrm{Cl} / \mathrm{NO}_{3}$ ratios were significantly higher in the $\mathrm{BS}$ than in the AF. When individual distances from the ditch were assessed only locations closest to the ditch were

Table 2 Average $\mathrm{Cl}$ and $\mathrm{NO}_{3}-\mathrm{N}$ concentrations $\left(\mathrm{mg} \mathrm{l}^{-1}\right)$ as a function of distance to the ditch (DIST) and as a function of location buffer (BS) or arable field (AF) (BS/AF)

\begin{tabular}{|c|c|c|c|c|c|c|c|c|}
\hline & & \multirow[t]{3}{*}{ Location } & \multicolumn{6}{|c|}{ Distance to the ditch $(\mathrm{m})$} \\
\hline & & & \multicolumn{2}{|l|}{ BS } & \multicolumn{4}{|l|}{$\mathrm{AF}$} \\
\hline & & & 0.5 & 3 & 4 & 9 & 40 & 100 \\
\hline \multirow[t]{2}{*}{ 2003-2004 } & $\mathrm{NO}_{3}-\mathrm{N}$ & $\begin{array}{l}\text { DIST } \\
\text { BS/AF }\end{array}$ & $\begin{array}{l}7.02^{\mathrm{a}} \\
9.05^{\mathrm{a}}\end{array}$ & $10.95^{\mathrm{b}}$ & $\begin{array}{l}12.63^{\mathrm{b}} \\
15.14^{\mathrm{b}}\end{array}$ & $18.21^{\mathrm{b}}$ & $14.81^{\mathrm{b}}$ & $14.91^{\mathrm{b}}$ \\
\hline & $\mathrm{Cl} / \mathrm{NO}_{3}-\mathrm{N}$ & $\begin{array}{l}\text { DIST } \\
\text { BS/AF }\end{array}$ & $\begin{array}{l}28.70^{\mathrm{a}} \\
18.30^{\mathrm{a}}\end{array}$ & $8.70^{\mathrm{b}}$ & $\begin{array}{l}11.70^{\mathrm{b}} \\
5.00^{\mathrm{b}}\end{array}$ & $2.40^{\mathrm{b}}$ & $2.80^{\mathrm{b}}$ & $3.00^{\mathrm{b}}$ \\
\hline \multirow[t]{2}{*}{ 2004-2005 } & $\mathrm{NO}_{3}-\mathrm{N}$ & $\begin{array}{l}\text { DIST } \\
\text { BS/AF }\end{array}$ & $\begin{array}{r}8.18^{\mathrm{a}} \\
13.94^{\mathrm{a}}\end{array}$ & $19.71^{\mathrm{a}}$ & $\begin{array}{l}26.49^{\mathrm{b}} \\
28.90^{\mathrm{b}}\end{array}$ & $35.00^{\mathrm{b}}$ & $28.53^{\mathrm{b}}$ & $25.59^{\mathrm{b}}$ \\
\hline & $\mathrm{Cl} / \mathrm{NO}_{3}-\mathrm{N}$ & $\begin{array}{l}\text { DIST } \\
\text { BS/AF }\end{array}$ & $\begin{array}{l}26.30^{\mathrm{a}} \\
20.00^{\mathrm{a}}\end{array}$ & $13.60^{\mathrm{b}}$ & $\begin{array}{c}9.70^{\mathrm{b}} \\
3.80^{\mathrm{b}}\end{array}$ & $1.70^{\mathrm{b}}$ & $1.60^{\mathrm{b}}$ & $2.30^{\mathrm{b}}$ \\
\hline
\end{tabular}

Values with different letters in superscript differ significantly $(p<0.05)$ from those within the same row. Due to missing values and rounding errors the values for BS/AF may differ from the average of the corresponding DIST values 


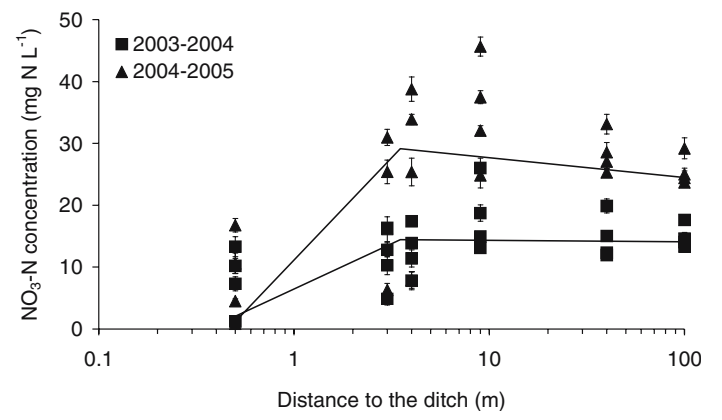

Fig. 5 Season-averaged $\mathrm{NO}_{3}-\mathrm{N}$ concentrations for different transects with distance to the ditch. Lines show linear trends according to Eq. (2). Error bars show standard errors $(n=10)$

significantly different (Table 2). In the first leaching season $\mathrm{Cl}$ concentrations were not significantly different among locations, but in the second leaching season $\mathrm{Cl}$ concentrations in the BS were significantly lower (not shown). $\mathrm{Cl} / \mathrm{NO}_{3}-$ $\mathrm{N}$ ratios generally increased towards the ditch indicating that for both leaching seasons $\mathrm{NO}_{3}$ was removed from the soil solution, since no input of $\mathrm{Cl}$ was observed. However, the most obvious change in $\mathrm{Cl} / \mathrm{NO}_{3}$ ratios was on the headland of the arable field (between $4 \mathrm{~m}$ and $9 \mathrm{~m}$ ) (Table 2) used as turning point of agricultural machinery that may have caused compaction and overlap of fertiliser lanes resulting in higher $\mathrm{NO}_{3}$ contents. When the headland was removed from the dataset the abovementioned differences between $\mathrm{BS}$ and AF were still valid and therefore the increase of $\mathrm{NO}_{3}$ contents at $4 \mathrm{~m}$ did not affect the overall conclusions that $\mathrm{NO}_{3}$ concentrations in the $\mathrm{BS}$ were below $\mathrm{NO}_{3}$ concentrations in the $\mathrm{AF}$.

The average $\delta^{15} \mathrm{~N}$ value of $\mathrm{NO}_{3}$ in groundwater was $0.97 \pm 5.71 \% \quad(n=138)$ and $\delta^{15} \mathrm{~N}$ values ranged between $-11.03 \%$ to $22.39 \%$. The $\delta^{15} \mathrm{~N}$ values showed a slight increase in time (not shown). Below the peat layer $\delta^{15} \mathrm{~N}$ values were significantly higher than above the peat layer $(p<0.0001)$. There was a negative relation between distance from ditch and $\delta^{15} \mathrm{~N}$ values for

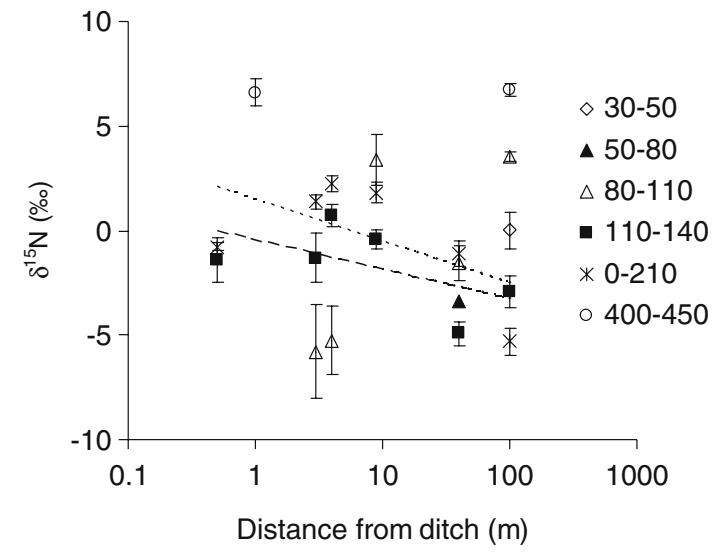

Fig. 6 Average $\delta^{15} \mathrm{~N}$ values (\%) at various distances from the ditch $(\mathrm{m})$ and depths $(\mathrm{cm})$. Averages are replicated in time and error bars show standard errors $(n=2-14)$. Lines show logarithmic regressions for depth $=105 \mathrm{~cm}$-ss (long dash, $R^{2}=0.34$ ) and for depth $=125 \mathrm{~cm}$-ss (short dash, $R^{2}=0.34$ )

some depths (105 cm -ss and $125 \mathrm{~cm}$-ss) (Fig. 6), but for other depths no relation with distance from the ditch was found, which might have been caused by preferential flow pathways and contribution from other sources, but we could not explain this finding in detail.

\section{Discharge and $\mathrm{NO}_{3}-\mathrm{N}$ load to ditch}

The discharge to the ditch and the corresponding computed load of $\mathrm{NO}_{3}-\mathrm{N}$ is shown in Fig. 7. The discharge of water is much less than the average effective rainfall reported above $(275 \mathrm{~mm})$, on average a factor 4.2 higher, indicating that quite some effective rainfall was groundwater recharge. The average load of $\mathrm{NO}_{3}-\mathrm{N}$ to the ditch was approximately $9 \mathrm{~kg} \mathrm{~N} \mathrm{ha}^{-1}$ for both leaching seasons.

\section{Discussion}

In the Netherlands, buffer strips are widely used to decrease direct contamination of surface water

Table 3 Optimised regression coefficients $b_{0}, b_{1}$ and $b_{2}$ (standard error between brackets) of the piece-wise linear regression model (Eq. 1), residual variance $\sigma^{2}$, and adjusted percentage of variance accounted for $R_{\text {adj }}^{2}$

\begin{tabular}{llllr}
\hline Season & $b_{0}$ & $b_{1}$ & $b_{2}$ & $\sigma^{2}$ \\
\hline $2003-2004$ & $-0.02(1.22)$ & $4.137(0.487)$ & $-4.141(0.497)$ & 8.545 \\
$2004-2005$ & $-3.456(0.922)$ & $9.313(0.922)$ & $-9.361(0.957)$ & 10.04 \\
\hline
\end{tabular}




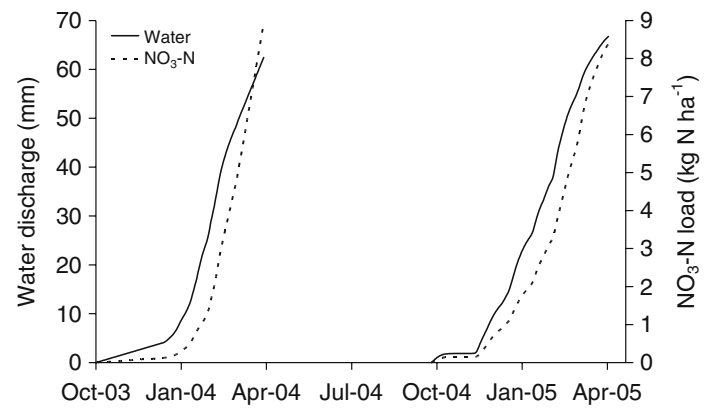

Fig. 7 Cumulative discharge of water and cumulative load of $\mathrm{NO}_{3}-\mathrm{N}$ towards the ditch for both leaching seasons according to Eq. (3) and Eq. (4)

by drift of pesticides and to increase biodiversity of field-margins. The present study does not quantify the effect of BSs on $\mathrm{N}$ loads to surface water, but the reductions in $\mathrm{NO}_{3}$ concentrations in groundwater in the BS as observed in this study are a strong indication that $\mathrm{NO}_{3}$ was actively removed in the $\mathrm{BS}$, eventually resulting in decreased $\mathrm{N}$ loads to surface water. The observed decrease in $\mathrm{NO}_{3}$ concentrations may be due to dilution, uptake and/or denitrification. In this section, we will discuss these different $\mathrm{NO}_{3}$ affecting processes in order to understand the functioning of the BS.

Figures 3 and 4 showed that at rising water tables the $\mathrm{NO}_{3}$ concentrations increased and apparently a change in gradient is followed by a change in concentration. In general, the $\mathrm{NO}_{3}$ concentration in soil solution decreases with depth. As groundwater rises it is likely that the water inside the fully perforated well is enriched with soil water with higher nitrate concentrations. As the average groundwater level rises in time under $\mathrm{AF}$, this explains the increase in $\mathrm{NO}_{3}$ concentrations under AF. A similar explanation cannot be used for the rise in $\mathrm{NO}_{3}$ observed under BS. Firstly, the groundwater levels don't rise as high as in the AF, and, secondly, the $\mathrm{NO}_{3}$ concentrations in the top soil under BS were much lower since this part of the field was not fertilised. The only explanation for this rise of the $\mathrm{NO}_{3}$ concentrations must be sought in lateral enrichment from outside the BS. Since it takes time for solutes to be transported from AF to BS, the rise in $\mathrm{NO}_{3}$ lags behind the rise under $\mathrm{AF}$, as is seen in Fig. 4. From an hydrological point of view this lateral movement of water is justified as follows. The BS comprises $3.5 \%$ (BS width is $3.5 \mathrm{~m}$, and half the distance between tow ditches is $100 \mathrm{~m}$ ) of the total discharge area of the ditch. The effective rainfall was on average $275 \mathrm{~mm}$. The contribution of the BS to the discharge then equals approximately $10 \mathrm{~mm}$. The estimated discharge to the ditch was on average $65 \mathrm{~mm}$, so that $55 \mathrm{~mm}$ must have passed the BS in order to reach the ditch and hence concentration fronts of $\mathrm{NO}_{3}$ from the AF reach the BS after some time.

The computed load of $\mathrm{NO}_{3}$ to the ditch was on average $9 \mathrm{~kg} \mathrm{~N} \mathrm{ha}^{-1}$ for both leaching seasons. Additional discharge and load occurs during the growing season and therefore on an annual basis the $\mathrm{NO}_{3}$ load to the ditch will be somewhat higher. However, the estimated $\mathrm{NO}_{3}$ load in this study seems somewhat low compared to the national inventory of $\mathrm{N}$ loads to surface water (MNP RIVM 2002), which report total-N loads of $25 \mathrm{~kg} \mathrm{ha}^{-1} \mathrm{yr}^{-1}$ for this region.

Below the $\mathrm{BS}$ increased $\mathrm{Cl} / \mathrm{NO}_{3}$ ratios were found (Table 2) indicating $\mathrm{NO}_{3}$ consuming processes. It is unlikely that this local increase was caused by dilution with rainwater considering the $\mathrm{Cl} / \mathrm{NO}_{3}$ ratio of approximately 2 for rainwater (National Monitoring Programme Rainwater Composition 1999). Also, during periods with excess rainfall and downward leakage across the peat layer, no increase in $\mathrm{Cl} / \mathrm{NO}_{3}$ ratios was observed.

Another explanation may be grass uptake of $\mathrm{NO}_{3}$ in the BS. On average $55 \mathrm{~kg} \mathrm{~N} \mathrm{ha}^{-1} \mathrm{yr}^{-1}$ was removed from the buffer strip, of which $8 \mathrm{~kg}$ $\mathrm{N} \mathrm{ha}^{-1} \mathrm{yr}^{-1}$ was taken up during the leaching season (Van Beek et al. 2005). This uptake can only partially explain the lower $\mathrm{Cl} / \mathrm{NO}_{3}$ ratios below the $\mathrm{BS}$, considering that a decrease of on average $6 \mathrm{mg} \mathrm{l}^{-1} \mathrm{NO}_{3}-\mathrm{N}$ between the $\mathrm{AF}$ and the BS (Table 2) corresponds with about $5 \mathrm{~kg} \mathrm{~N} \mathrm{ha}^{-1}$ (rooting depth $=20 \mathrm{~cm}$ (Van Beek et al. 2005), $\varphi=0.4 \mathrm{~m}^{3} \mathrm{~m}^{-3}$ (effective porosity, De Vos et al. 2002)).

Therefore, we assume that the majority of the $\mathrm{NO}_{3}$ removal in the BS was due to denitrification, which was supported with the observed changes in $\delta^{15} \mathrm{~N}$ and in $\mathrm{Cl} / \mathrm{NO}_{3}$ ratios (Table 2 and Fig. 6). In Fig. 6 the $\delta^{15} \mathrm{~N}$ values at $425 \mathrm{~cm}$-ss were divergent from results at shallower depth. At 
$425 \mathrm{~cm}$-ss, i.e. below the peat layer, groundwater was older, resulting in higher $\delta^{15} \mathrm{~N}$ values (Mayer et al. 2002). In previous studies on the same site, actual denitrification rates in soil were estimated at about $5 \mathrm{~kg} \mathrm{~N} \mathrm{ha}^{-1} \mathrm{yr}^{-1}$ (Assinck and De Willigen 2004). However, these estimations were on field level and could not reveal spatial gradients causing the $\mathrm{NO}_{3}$ decrease below the BS. Denitrification can only occur in presence of an energy source, typically organic matter. Therefore, we determined total organic carbon (TOC) concentrations in the groundwater samples to check whether there was a spatial component in the TOC concentrations. TOC was detectable in all samples, but there was no gradient in TOC with distance to the ditch (data not shown).

Figure 5 showed a decrease in $\mathrm{NO}_{3}-\mathrm{N}$ concentrations with distance to the ditch in the AF, and on average highest $\mathrm{NO}_{3}-\mathrm{N}$ concentrations were found just before the BS. This location coincides with the turning point of agricultural machinery and we presume that the relatively high $\mathrm{NO}_{3}-\mathrm{N}$ concentrations just before the BS were caused by compaction, overlap of fertiliser lanes and subsequently higher nutrient surpluses due to decreased crop uptake.

\section{Conclusions}

Due to the prevailing hydrological conditions in Dutch agricultural fields in general low efficiencies of bufferstrips in retaining nutrients from leaching to surface water were expected. In this study however we found clear results of decreased $\mathrm{NO}_{3}-\mathrm{N}$ concentrations below a bufferstrip as compared to the arable field. Most likely the decrease in $\mathrm{NO}_{3}-\mathrm{N}$ concentrations in the bufferstrip was mainly due to denitrification. Although we cannot definitely conclude that the decrease in $\mathrm{NO}_{3}-\mathrm{N}$ concentrations were primarily due to the presence of a non-fertilised buffer strip, because of lack of a reference situation, the results are promising for the application of bufferstrips to reduce $\mathrm{N}$ loading of surface water under Dutch conditions.

Acknowledgements This study was funded by the Dutch ministry of Agriculture, Nature and Food Quality within the research programme 398-II 'Mest en Mineralenprogramma'. We thank Jan van Kleef, Dick Brus (both Alterra) and David Harris (UC Davis) for their assistance in carrying out this study and Gerard Velthof (Alterra) for critically reviewing previous versions of this paper.

\section{References}

Altman SJ, Parizek RR (1995) Dilution of nonpointsource nitrate in ground water. $\mathrm{J}$ Environ Qual 24:707-718

Assinck FBT, De Willigen P (2004) Stikstofstromen op het kernbedrijf Vredepeel. Modelberekeningen met FUSSIM2 en MOTOR. Telen met Toekomst OVO402

Bedard-Haughn A, Van Groenigen JW, Van Kessel C (2003) Tracing ${ }^{15} \mathrm{~N}$ through landscapes: potential uses and precautions. J Hydr 272:175-190

Boesten JJTI, van der Pas LJT (2000) Movement of water, bromide and the pesticides ethoprophos and bentazone in a sandy soil: the Vredepeel data set. Agr Water Manage 44:21-42

Borin M, Bigon E (2002) Abatement of $\mathrm{NO}_{3}-\mathrm{N}$ concentration in agricultural waters by narrow buffer strips. Environ Pollut 117:165-168

De Bruin HAR (1987) From Penman to Makkink. In: Hooghart JC (ed) Evaporation and weather. Proceedings and Information No. 39, TNO Committee on Hydrological Research, TNO, The Hague, The Netherlands, pp 5-31

De Klein JJM, Hefting MM (1998) Nitrogen dynamics in bufferstrips along lowland streams. In: Roijackers R, Aalderink RH, Blom G (eds) Eutrophication research: state-of-the-art: inputs, processes, effects, modelling, management, Proceedings 28-29 August 1997. Wageningen Agricultural University, Wageningen, The Netherlands, pp 35-42

De Vos JA, Hummelink EWJ, Van Steenbergen TS (2002) Waterretentie en waterdoorlatendheidskarakteristieken van Telen met Toekomstproefvelden Meterik en Vredepeel (in Dutch). Telen met Toekomst Rapport OVO204, Plant Research International, Wageningen

De Vries JJ (1974) Groundwater flow systems and stream nets in the Netherlands: a groundwater-hydrologic approach to the functional relationship between the drainage system and the geological and climatical conditions in a Quaternary accumulation area. $\mathrm{PhD}$ Thesis, Vrije Universiteit, Amsterdam, the Netherlands

Dhondt K, Boeckx P, Van Cleemput O, Hofman G, De Troch F (2002) Seasonal groundwater nitrate dynamics in a riparian buffer zone. Agronomie 22:747-753

Dinnes DL, Karlen DL, Jaynes DB, Kaspar TC, Hatfield JL, Colvin TS, Cambardella CA (2002) Nitrogen management strategies to reduce nitrate leaching in tile-drained midwestern soils. Agron J 94:153-171 
Haycock NE, Burt TP (1993) Role of floodplain sediments in reducing the nitrate concentration of subsurface run-off: a case study in the Cotswolds, UK. Hydrol Process 7:287-295

Haycock NE, Pinay G (1993) Groundwater nitrate dynamics in grass and poplar vegetated riparian buffer strips during the winter. J Environ Qual 22:273-278

Hefting MM (2003) Nitrogen transformation and retention in riparian buffer zones. $\mathrm{PhD}$ Thesis, University of Utrecht, The Netherlands

Hefting MM, De Klein JJM (1998) Nitrogen removal in buffer strips along a lowland stream in the Netherlands: a pilot study. Environ Pollut 102:521-526

Komor SC, Magner JA (1996) Nitrate in groundwater and water sources used by riparian trees in an agricultural watershed: a chemical and isotopic investigation in southern Minnesota. Water Resour Res 32:1039-1050

Kuusemets V, Mander U, Lohmus K, Ivask M (2001) Nitrogen and phosphorus variation in shallow groundwater and assimilation in plants in complex riparian buffer zones. Water Sci Technol 44:615-622

Leeds-Harrison PB, Quinton JN, Walker MJ, Sanders CL, Harrod T (1999) Grassed buffer strips for the control of nitrate leaching to surface waters in headwater catchments. Ecol Eng 12:299-313

Lowrance R, Hubbard RK, Williams RG (2000) Effects of a managed three zone riparian buffer system on shallow groundwater quality in the southeastern coastal plain. J Soil Water Conserv 55:212-220

Lowrance R, Todd R, Fail J, Hendrickson O, Leonard R, Asmussen L (1984) Riparian forests as nutrient filters in agricultural watersheds. Bioscience 34:374-377

Makkink GF (1957) Testing the Penman formula by means of lysimeters. J Inst Water Eng 11:277-288

Marschner H (2002) Mineral nutrition of higher plants, 2nd edn. Academic Press

Mayer B, Boyer EW, Goodale CL, Jaworski NA, Van Breemen N, Howarth RW, Seitzinger SP, Billen G, Lajtha K, Nadelhoffer KJ, van Dam D, Hetling LJ, Nosal M, Paustian K (2002) Sources of nitrate in rivers draining sixteen watersheds in the northeastern U.S.: isotopic constraints. Biogeochemistry 57/58:171197

Mengis M, Schiff SL, Harris M, English MC, Aravena R, Elgood RJ, MacLean A (1999) Multiple geochemical and isotopic approaches for assessing ground water $\mathrm{NO}_{3}$ elimination in a riparian zone. Ground Water 37:448-457

MNP RIVM (2002) MINAS en MILIEU. Balans en verkenning. RIVM-rapport 718201005, RIVM, Bilthoven, the Netherlands, $205 \mathrm{pp}$

Muscutt AD, Harris GL, Bailey SW, Davies DB (1993) Buffer zones to improve water-quality - a review of their potential use in UK agriculture. Agr Ecosyst Environ 45:59-77

Novak JM, Hunt PG, Stone KC, Watts DW, Johnson MH (2002) Riparian zone impact on phosphorus movement to a Coastal Plain black water stream. J Soil Water Conserv 57:127-133

Oenema O, Roest CWJ (1998) Nitrogen and phosphorus losses from agriculture into surface waters; the effects of policies and measures in The Netherlands. Wetlands Sci Technol 37:19-30

Orleans ABM, Mugge FLT, Van der Meij T, Vos P, Ter Keurs WJ (1994) Minder nutriënten in het oppervlaktewater door bufferstroken? Een literatuuranalyse (in Dutch). Milieubiologie, Rijksuniversiteit Leiden

Penman HL (1948) Natural evapotranspiration from open water, bare soil and grass. Proc $\mathrm{R}$ Soc Lond A 193:120-145

PeterJohn WT, Correll DL (1984) Nutrient dynamics in an agricultural watershed; Observations on the role of riparian forest. Ecology 65:1466-1475

Priestley CHB, Taylor RJ (1972) On the assessment of the surfaces heat flux and evaporation using large scale parameters. Mon Weather Rev 100: 81-92

Sabater S, Butturini A, Clement J-C, Burt T, Dowrick D, Hefting MM, MaÎtre V, Pinay G, Postolache C, Rzepecki M, Sabater F (2003) Nitrogen removal by riparian buffers along a European climatic gradient: patterns and factors of variation. Ecosystems 6:20-30

Stark JM, Hart SC (1996) Diffusion technique for preparing salt solutions, Kjeldahl digests, and persulfate digests for Nitrogen-15 analysis. Soil Sci Soc Am J 60:1846-1855

Van Beek CL, Clevering OA, Van Kleef J, Heinen M (2005) Nitraatconcentraties in het bovenste grondwater naast en onder een bufferstrook. Resultaten van twee jaar experimenteel onderzoek aan een gras bufferstrook op zandgrond op akkerbouwbedrijf Vredepeel (in Dutch). Alterra-rapport 1263, Alterra, Wageningen, The Netherlands

Van der Ploeg RR, Horton R, Kirkham D (1999) Steady flow to drains and wells. In: Skaggs RW, van Schilfgaarde J (eds) Agricultural drainage. Agronomy Series No. 38, ASA-CSSA-SSSA, Madison, WI, pp 213-263

Van Groenigen JW, Georgius PJ, Van Kessel C, Hummelink EWJ, Velthof GL, Zwart KB (2005) Subsoil ${ }^{15} \mathrm{~N}-\mathrm{N}_{2} \mathrm{O}$ concentrations in a sandy soil profile after application of ${ }^{15} \mathrm{~N}$-fertilizer. Nutr Cycl Agroecosyst 72:13-25

Vought LB-M, Dahl J, Lauge Pedersen C, Lacoursière JO (1994) Nutrient retention in riparian ecotones. Ambio 23:342-348 